\title{
The effects of adult small hive beetles, Aethina tumida (Coleoptera: Nitidulidae), on nests and flight activity of Cape and European honey bees (Apis mellifera)
}

\author{
James D. Ellis Jr. ${ }^{\text {a*}}$, Randall HePBURNa ${ }^{\mathrm{a}}$, Keith S. DELAPLANE ${ }^{\mathrm{b}}$, Peter NEUMANNc, \\ Patti J. ELZEN ${ }^{\mathrm{d}}$

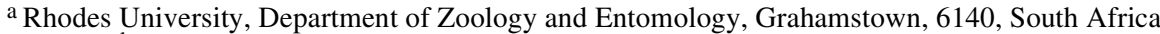

$\mathrm{b}$ University of Georgia, Department of Entomology, Athens, GA 30602, USA

${ }^{c}$ Institut für Zoologie, Martin-Luther-Universität Halle-Wittenberg, 06099, Halle/Saale, Germany

d USDA, Kika de la Garza Subtropical Research Center, Weslaco, TX, 78596, USA
\end{abstract}

(Received 26 September 2002; revised 24 December 2002; accepted 6 February 2003)

\begin{abstract}
This study identifies differences in the effects of small hive beetles on flight activity and nests of European-derived honey bees (Apis mellifera) in the United States and Cape honey bees (Apis mellifera capensis) in South Africa. Treatments consisted of control colonies ( $<5$ beetles/colony) and experimental colonies receiving beetles (treatment). Absconding day did not differ significantly between treatment or bee race but absconding was greater between the two treatments in European colonies than in Cape ones. Cape bees used significantly more propolis than European bees. Honey stores were significantly greater in Cape honey bee colonies than in European ones. Bee weight did not differ significantly between treatments or bee race. Treatment did not significantly affect bee populations, brood area, or average flight activity in Cape colonies but it did significantly lower all of these in European colonies. The effects of treatment in European colonies are symptomatic of absconding preparation. Treatment significantly lowered the amount of pollen stores in Cape colonies, but this effect was not found in European colonies. The number of beetles in control colonies was significantly higher in European colonies than Cape ones while the percentage of beetles remaining in non-absconding treated colonies was higher in Cape colonies than European ones. These data indicate that adult small hive beetles are sufficient to cause significant harmful effects on colonies of European, but not Cape, honey bees.
\end{abstract}

Aethina tumida / Apis mellifera / Apis mellifera capensis / flight activity / honey bee nests

\section{INTRODUCTION}

Small hive beetles (Aethina tumida Murray) are native to honey bee colonies (Apis mellifera L.) of sub-Saharan Africa where the beetle's pest status is negligible (Hepburn and Radloff, 1998). Successful reproduction of the beetle in its native range is often restricted to weak host colonies, due to behavioral resistance mechanisms of their honey bee hosts (Elzen et al., 2001; Neumann et al., 2001a), or is associated with after absconding events (Hepburn et al., 1999). Absconding is frequent in African honey bee subspecies and can be

\footnotetext{
* Correspondence and reprints

E-mail: g01e3989@campus.ru.ac.za
} 
triggered by parasite infestations (Hepburn and Radloff, 1998). Indeed, severe small hive beetle infestations may cause such absconding (Hepburn and Radloff, 1998).

In sharp contrast, colonies of Europeanderived honey bee subspecies are highly susceptible to small hive beetle depredation (Elzen et al., 1999; Hood, 2000; Wenning, 2001). This damage stems from the feeding habits of both adult and larval beetles (Hood, 2000). It has been reported that only the larval stage presents a direct threat to colony health and European colonies can host thousands of adult hive beetles without suffering visible side effects (Wenning, 2001); however, no quantitative study has confirmed this.

Such quantitatively different responses of Cape (and presumably most other African subspecies) and European host colonies towards adult small hive beetles are very likely to be reflected in colony productivity. Since European honey bees are highly susceptible, a reduction in colony productivity is more likely to be expressed in European host colonies than in Cape ones. Although the impact of hive beetles on European host colonies is striking, this effect has not yet been measured quantitatively.

Here we report the results of an intercontinental quantitative study of the productivity of artificially infested or non-infested Cape (A.m. capensis) and European honey bee colonies. The variables measured included absconding day, total propolis, honey stores, bee weight, sealed brood, number of adult bees, pollen stores, flight activity and the number of small hive beetles remaining in treated colonies of Cape honey bees in South Africa and European honey bees of mixed origin in the United States.

\section{MATERIALS AND METHODS}

\subsection{Cape honey bees}

Experiments were conducted at Rhodes University (Grahamstown, South Africa) in late summer/ early fall (April 2001). Twenty propolis-free nucleus colonies (about 201 in volume) of Cape honey bees (an African honey bee subspecies that is geographically distributed in the region of study) were established with 3 frames of workers, 1 frame of honey, 2 frames of brood, and a laying queen. Ten treated colonies were artificially infested with 100 adult small hive beetles on a daily basis between 17:00-21:00 $\mathrm{h}$ for 15 consecutive days. The small hive beetles used were reared in the laboratory according to standard procedures (Neumann et al., 2001b). By the end of the experiment, 1500 beetles (100 beetles/colony for 15 days) had been introduced into all of the treated colonies. This level of beetle infestation is high for African honey bee colonies, but is common in infested European ones. Ten control colonies ( $<5$ beetles/colony) were otherwise treated identically to the treated colonies. All nucs were placed in the same apiary, blocked together by treatment.

The number of returning bees was counted for all colonies twice daily, 1 minute each count, between 11:00-11:40 and 15:00-15:40 $\mathrm{h}$ because of data indicating peak foraging times for honey bees at 11:00 and 15:00 in southern Africa (Hepburn and Magnuson, 1988). Overall flight activity was determined by averaging the number of incoming bees per minute for both times.

Each colony was monitored three times daily (11:00, 15:00, 20:00) to identify its date of absconding, immediately after which, the colony was dismantled to determine number of adult small hive beetles present; sealed brood area $\left(\mathrm{cm}^{2}\right)$, honey area $\left(\mathrm{cm}^{2}\right)$, and pollen area $\left(\mathrm{cm}^{2}\right)$ (using a calibrated plastic grid); and total weight of propolis ( $\mathrm{g}$ ) in the colony.

On the evening of day 16 all remaining colonies were closed up, gassed with $\mathrm{CO}_{2}$, frozen at $-10^{\circ} \mathrm{C}$, and then analyzed. For each colony, data were collected for the amount of sealed brood, honey, and pollen $\left(\mathrm{cm}^{2}\right)$, number of adult small hive beetles, total weight of bees $(\mathrm{g})$, weight of a sub-sample of bees $(\mathrm{g})$ and number of bees in the sample (used to derive the number of bees in the colony), and total weight of propolis $(\mathrm{g})$.

\subsection{Honey bees of mixed European origin}

A modified procedure was conducted on honey bees of mixed European origin (unknown history) in Warren County, Georgia, USA in late summer/ early fall (August/September 2001). Adult beetles were reared from larvae collected in the field. The larvae were supplemented on a diet of pollen, honey, and bee brood (Neumann et al., 2001b; Ellis et al., 2002b) until they reached the wandering phase (Lundie, 1940), after which they were transferred to soil chambers for pupation and emersion as adults. Each treated European colony cumulatively received 1400 beetles (100 beetles/day for 14 days). 
Table I. Analyses of absconding day, honey area $\left(\mathrm{cm}^{2}\right)$, total propolis $(\mathrm{g})$, and bee weight $(\mathrm{mg})$ for Cape and European host colonies. Values are mean \pm standard error with sample size $(n)$ in parentheses.

\begin{tabular}{|c|c|c|c|c|c|c|c|}
\hline \multicolumn{4}{|c|}{ absconding day } & \multicolumn{4}{|c|}{ honey area } \\
\hline & treatment & control & row total & & treatment & control & row total \\
\hline Cape & $\begin{array}{c}7.3 \pm 2.0 \\
(6)\end{array}$ & $\begin{array}{c}6.3 \pm 2.6 \\
(4)\end{array}$ & $\begin{array}{c}6.9 \pm 1.5 \\
(10) \mathrm{a}\end{array}$ & Cape & $\begin{array}{c}663.8 \pm 82.7 \\
\text { (4) }\end{array}$ & $\begin{array}{c}960.0 \pm 124.9 \\
(5)\end{array}$ & $\begin{array}{c}828.3 \pm 90.5 \\
\text { (9)a }\end{array}$ \\
\hline European & $\begin{array}{c}7.5 \pm 2.2 \\
(6)\end{array}$ & $\begin{array}{c}17.0 \pm 0 \\
(1)\end{array}$ & $\begin{array}{c}8.9 \pm 2.3 \\
(7) \mathrm{a}\end{array}$ & European & $\begin{array}{c}0 \pm 0 \\
(4)\end{array}$ & $\begin{array}{c}115.6 \pm 38.9 \\
\text { (9) }\end{array}$ & $\begin{array}{c}80.0 \pm 30.6 \\
(13) b\end{array}$ \\
\hline $\begin{array}{l}\text { column } \\
\text { total }\end{array}$ & $\begin{array}{c}7.4 \pm 1.4 \\
(12) \mathrm{a}\end{array}$ & $\begin{array}{c}8.4 \pm 2.9 \\
(5) \mathrm{a}\end{array}$ & & $\begin{array}{l}\text { column } \\
\text { total }\end{array}$ & $\begin{array}{c}331.9 \pm 131.1 \\
(8) \mathrm{a}\end{array}$ & $\begin{array}{c}417.1 \pm 122.1 \\
(14) b\end{array}$ & \\
\hline \multicolumn{4}{|c|}{ total propolis (g) } & \multicolumn{4}{|c|}{ bee weight (mg) } \\
\hline & treatment & control & row total & & treatment & control & row total \\
\hline Cape & $\begin{array}{c}15.5 \pm 3.1 \\
(8)\end{array}$ & $\begin{array}{c}10.8 \pm 2.3 \\
(8)\end{array}$ & $\begin{array}{c}13.1 \pm 2.0 \\
(16) \mathrm{a}\end{array}$ & Cape & $\begin{array}{c}91.4 \pm 4.4 \\
\text { (4) }\end{array}$ & $\begin{array}{c}91.3 \pm 4.1 \\
(5)\end{array}$ & $\begin{array}{c}91.4 \pm 2.8 \\
(9) \mathrm{a}\end{array}$ \\
\hline European & $\begin{array}{c}3.7 \pm 0.6 \\
(10)\end{array}$ & $\begin{array}{c}3.2 \pm 0.4 \\
(10)\end{array}$ & $\begin{array}{l}3.5 \pm 0.3 \\
(20) \mathrm{b}\end{array}$ & European & $\begin{array}{c}87.6 \pm 3.1 \\
\text { (4) }\end{array}$ & $\begin{array}{c}95.3 \pm 1.7 \\
(9)\end{array}$ & $\begin{array}{c}92.9 \pm 1.8 \\
(13) \mathrm{a}\end{array}$ \\
\hline $\begin{array}{l}\text { column } \\
\text { total }\end{array}$ & $\begin{array}{l}9.0 \pm 2.0 \\
\quad(18) \mathrm{a}\end{array}$ & $\begin{array}{c}6.6 \pm 1.4 \\
(18) \mathrm{a}\end{array}$ & & $\begin{array}{l}\text { column } \\
\text { total }\end{array}$ & $\begin{array}{c}89.5 \pm 2.6 \\
(8) \mathrm{a}\end{array}$ & $\begin{array}{c}93.9 \pm 1.8 \\
\quad(14) \mathrm{a}\end{array}$ & \\
\hline
\end{tabular}

Row total and column total means followed by the same letter are not different at the $\alpha \leq 0.05$ level. For the variables absconding day and total propolis, analyses were run including absconding colonies. For the variables honey area and bee weight, analyses were run without including absconding colonies.

European colonies which did not abscond in the experimental period were collected early morning on the 17 th day of the experiment, cooled at $7^{\circ} \mathrm{C}$ for 1 day, and then frozen for an analysis identical to that done on non-absconding Cape bee colonies.

\subsection{Data analysis}

The effects of treatment [small hive beetles added or not added (control)] on absconding day, total propolis content, honey area, bee weight, number of bees, sealed brood and pollen area, and average flight activity were tested with a randomized design analysis of variance, blocked on location (United States or South Africa) and accepting differences at the $\alpha \leq 0.05$ level. When the treatment $\times$ location interaction was significant, analyses were run separately by location. For the variables absconding day, total propolis content, brood and pollen area, analyses included absconding colonies. Absconding colonies were excluded from analyses of honey area, bee weight, and number of bees because these parameters were either unavailable or confounded in empty hives.

The effects of time and increasing beetle numbers on average daily bee flight activity were tested with regression analyses testing for linear, quadratic, and cubic effects.

The ending number of small hive beetles in nonabsconding control colonies and the percentage of beetles remaining in non-absconding treated colonies were analyzed for location effects with ANOVA. Beetle numbers in both absconding and non-absconding treated colonies were analyzed separately by location because the absconding $x$ location interaction was significant. All reported data are mean \pm standard error; $n$.

\section{RESULTS}

\subsection{Absconding}

There were no treatment effects $(F=1.6$; df $=1,13 ; P=0.2220)$, location effects $(F=$ $2.8 ; \mathrm{df}=1,13 ; P=0.1201)$, or location $\times$ treatment effects $(F=2.6$;f $=1,13 ; P=0.1308)$ for absconding day. Treated colonies did not abscond earlier than control colonies (Tab. I). In South Africa, $44 \%$ of control and $60 \%$ of treated colonies absconded while in the United States, $10 \%$ of control and $60 \%$ of treated colonies absconded.

Prior to absconding, treated European colonies aborted much of their brood. This was evident by the piles of mutilated brood on the ground outside of each colony. Further, worker bees were seen carrying brood out of the colony and discarding it on the ground. Upon post-absconding analysis of these colonies, no uncapped brood remained. 
Table II. Location $\times$ treatment interactions for amount of sealed brood $\left(\mathrm{cm}^{2}\right)$, number of adult bees, stored pollen area $\left(\mathrm{cm}^{2}\right)$, and average flight activity (number of bees returning per minute) in Cape and European host colonies. Values are mean \pm standard error with sample size $(n)$ in parentheses.

\begin{tabular}{|c|c|c|}
\hline & \multicolumn{2}{|c|}{ Cape colonies } \\
\hline & treatment & control \\
\hline sealed brood area & $201.9 \pm 78.8(10) \mathrm{a}$ & $205.6 \pm 58.3(9) \mathrm{a}$ \\
\hline number of adult bees & $6552.8 \pm 675.5(4) \mathrm{a}$ & $4823.4 \pm 675.4(5) \mathrm{a}$ \\
\hline stored pollen area & $27.7 \pm 11.2(10) \mathrm{a}$ & $116.9 \pm 37.1(9) b$ \\
\hline \multirow[t]{3}{*}{ average flight activity } & $9.6 \pm 0.7(102) \mathrm{a}$ & $10.9 \pm 0.8(114) \mathrm{a}$ \\
\hline & \multicolumn{2}{|c|}{ European colonies } \\
\hline & treatment & control \\
\hline sealed brood area & $54.1 \pm 18.0(10) \mathrm{a}$ & $739.7 \pm 191.6(10) b$ \\
\hline number of adult bees & $3246.8 \pm 234.3(4) \mathrm{a}$ & $6321.0 \pm 869.9(9) b$ \\
\hline stored pollen area & $67.5 \pm 42.4(10) \mathrm{a}$ & $25.1 \pm 8.6(10) \mathrm{a}$ \\
\hline average flight activity & $10.4 \pm 0.6(103) \mathrm{a}$ & $15.5 \pm 0.7(159) b$ \\
\hline
\end{tabular}

Analyses were run separately by location for these variables. For number of adult bees, analyses were run without including absconding colonies; for sealed brood and stored pollen area analyses included absconding colonies. Row means followed by the same letter are not different at the $\alpha \leq 0.05$ level.

\subsection{Propolis}

There were no treatment effects $(F=2.2$; $\mathrm{df}=1,32 ; P=0.1447)$ or location $\times$ treatment interactions $(F=1.4 ; \mathrm{df}=1,32 ; P=0.2461)$ for the amount of propolis in colonies. Treated colonies did not have more propolis than control colonies (Tab. I). There were location effects for the total propolis content $(F=30.1$; $\mathrm{df}=1,32 ; P<0.0001)$. Cape honey bee colonies had significantly more propolis than did European honey bee colonies (Tab. I).

\subsection{Honey area}

There were treatment $(F=7.5 ; \mathrm{df}=1,18$; $P=0.0136)$ and location $(F=100.4 ; \mathrm{df}=1,18$; $P<0.0001)$ effects for honey area. Control colonies had significantly more stored honey than treated colonies while Cape honey bees had significantly greater stores of honey than did European honey bees (Tab. I). There were no location $\times$ treatment interactions found for honey area $(F=1.4 ; \mathrm{df}=1,18 ; P=0.2455)$.

\subsection{Bee weight}

There were no treatment effects $(F=1.4$; $\mathrm{df}=1,18 ; P=0.2495)$, location effects $(F=0$; $\mathrm{df}=1,18 ; P=0.9746)$, or location $\times$ treatment interactions $(F=1.5 ; \mathrm{df}=1,18 ; P=0.2361)$ for bee weight. There were no differences in Cape and European colonies with respect to weight (Tab. I). Bee weight was not significantly different across all tested control and treated colonies (Tab. I).

\subsection{Brood area}

There was a significant location $\times$ treatment interaction for sealed brood area $(F=9.6 ; \mathrm{df}=$ 1,$35 ; P=0.0039$ ) so analyses were run separately by location. In Cape colonies, treatment did not significantly affect the amount of sealed brood $(F=0 ; \mathrm{df}=1,17 ; P=0.9712)$; yet it did in European colonies $(F=12.69$; df $=$ $1,18 ; P=0.0022)$. In European colonies there was significantly less brood in treated colonies than controls (Tab. II).

\subsection{Number of bees}

There was a significant location $\times$ treatment interaction for number of bees $(F=7.3$; df $=$ $1,18 ; P=0.0144)$ so analyses were run separately by location. In Cape colonies, treatment did not affect the number of bees in colonies $(F=3.2 ; \mathrm{df}=1,7 ; P=0.1174)$ while it did in the European colonies $(F=5.2 ; \mathrm{df}=1,11 ; P=$ 0.0432 ). European treated colonies had significantly fewer adult bees than control colonies (Tab. II). 


\subsection{Pollen area}

There was a significant location $\times$ treatment interaction for pollen area $(F=5.3$; df $=1,35$; $P=0.0276)$ so analyses were run separately by location. Treatment affected pollen area in Cape colonies $(F=5.8 ; \mathrm{df}=1,17 ; P=0.0278)$ whereas it did not in European bee colonies $(F=1.0 ; \mathrm{df}=1,18 ; P=0.3398)$. Cape treated colonies had significantly less pollen than control colonies (Tab. II).

\subsection{Flight activity}

There was a significant location effect for average flight activity $(F=13.3 ; \mathrm{df}=1,474$; $P=0.0003)$. European colonies $(13.5 \pm 0.5$; 262) had significantly more activity than Cape colonies $(10.2 \pm 0.6 ; 216)$. There was also a significant location $\times$ treatment interaction for average flight activity $(F=6.4 ; \mathrm{df}=1,474 ; P=$ 0.0120). In Cape colonies, treatment did not affect average flight activity $(F=1.40$; df $=$ $1,214 ; P=0.2387)$. Cape honey bee treated colonies had similar flight activity as control colonies (Tab. II). In contrast, treatment significantly affected average flight activity $(F=$ 25.8 ; df $=1,260 ; P<0.0001$ ) in European colonies. The number of incoming bees was significantly greater in control colonies than in treated colonies (Tab. II).

Regression analyses of flight activity trends over time reveal pronounced differences between locations (Fig. 1). In Cape colonies, average flight rates increased linearly over time in both treated and control colonies. Thus, flight activity appeared unaffected by increases in beetle numbers and the sampling period was universally and increasingly favorable for foraging. However, in European colonies there were measurable differences in trends between treated and control colonies. A cubic regression model in which rates fell, then rose, then fell again over time explained flight activity in treated colonies. A quadratic model in which rates rose then fell explained flight activity in control colonies. Rates were generally lower in treated colonies. Moreover, the increasing rates of flight by control colonies early in the sampling period contrast strongly with the decreasing rates by treated colonies at the time when conditions were apparently favorable for foraging. In spite of a

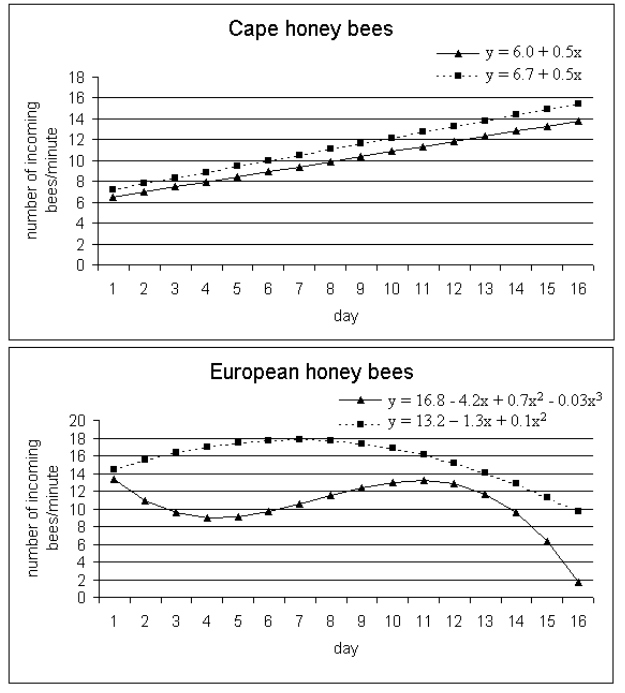

Figure 1. Predicted daily average number of returning workers for control and treated (beetles added) colonies of Cape and European-derived honey bees. Data were measured by averaging the number of incoming bees per minute at hours 11:00 and 15:00. Each day corresponds to an increase of 100 beetles/ colony. Control colonies are represented by black squares and dashed lines while treated colonies are black triangles with solid lines.

mid-period surge by treated colonies, rates began decreasing more rapidly in treated colonies by the end of the sampling period when foraging conditions appeared to be deteriorating universally and when rainy weather was prevalent.

\subsection{Beetle counts}

There were significant differences between locations for the number of small hive beetles present in control colonies at the end of the experiment $(F=14.0 ; \mathrm{df}=1,12 ; P=0.0028)$ and for the percentage of beetles remaining in non-absconding treated colonies $(F=18.0$; $\mathrm{df}=1,6 ; P=0.0054)$. There were significantly more beetles present in European control colonies $(12.9 \pm 1.3 ; 9)$ than in Cape control colonies $(5.6 \pm 1.3 ; 5)$. A significantly higher percentage of beetles remained in Cape bee non-absconding treated colonies $(87.8 \pm 0.7$; 4) than did in European bee non-absconding treated colonies $(42.1 \pm 10.7 ; 4)$. Indeed, that 
percentage was over twice as high for Cape bee colonies.

There were location effects $(F=13.2 ; \mathrm{df}=$ $1,16 ; P=0.0022)$ and location $\times$ absconding effects $(F=22.7 ; \mathrm{df}=1,16 ; P=0.0002)$ for the number of beetles remaining in absconding and non-absconding treated colonies. Cape treated colonies (pooled absconding and nonabsconding) had more beetles present (713.5 \pm $165.0 ; 10)$ at colony analyses than did European treated colonies $(481.3 \pm 83.3 ; 10)$. Because the interaction term was significant, the number of beetles left in absconding and non-absconding treated colonies was analyzed by location. For Cape honey bees, there was a significant difference between the number of beetles remaining in non-absconding and absconding treated colonies $(F=656.8$; $\mathrm{df}=$ $1,8 ; P<0.0001)$. Non-absconding treated colonies had significantly more beetles remaining $(1316.3 \pm 11.2 ; 4)$ than did absconding ones $(311.7 \pm 30.5 ; 6)$. For European colonies, there was no difference $(F=1.1 ; \mathrm{df}=1,8 ; P=$ 0.3174 ) between the number of beetles remaining in absconding treated colonies $(409.3 \pm 95.8 ; 6)$ and the number of beetles in non-absconding treated colonies $(589.3 \pm$ 150.3; 4).

\section{DISCUSSION}

\subsection{Absconding}

An analysis of absconding is of particular interest because most African honey bee subspecies readily abscond in response to nest predation (Hepburn and Radloff, 1998) while by contrast, temperate races of A. mellifera very seldom abscond (Simpson, 1959; Winston, 1992). In this study, control and treated colonies alike in both locations absconded; but there were no effects of treatment or location on the latency to abscond (Tab. I). For Cape bees, $44 \%$ of the controls absconded and $60 \%$ of treated colonies absconded. Because a large percentage of both Cape treatment and control colonies absconded, we infer other factors (colony disturbance, nectar dearth, etc.) caused them to abscond and not merely the presence of large numbers of adult small hive beetles.

Because $60 \%$ of European treated colonies absconded and only $10 \%$ of control colonies, we infer that, unlike Cape bees, European colonies absconded in response to the presence of large numbers of adult beetles in the hives. European colonies exhibited "prepared absconding" because these colonies had no uncapped young brood (based on post-abscond analyses), few workers emerged after the colony absconded, and honey stores were reduced. Other authors (Woyke, 1976; Winston et al., 1979; Koeniger and Vorwohl, 1979; Koeniger and Koeniger, 1980; Punchihewa, 1990; Nakamura, 1993; Mutsaers, 1994) record these symptoms as behavior typical of colonies preparing to abscond.

Moreover, European treated colonies (including the non-absconding colonies) uncapped and discarded all or most of their capped prepupae and pupae, as evidenced by the piles of mutilated pupae on the ground in front of treatment colonies. Further, bees were observed pulling pupae from the combs. By the end of the experiment, there was no open brood observed in any non-absconding European treated colony. These observations are similar to those of Woyke (1989) who showed that colonies of A. m. adansonii ate all of their uncapped larvae and most of their sealed brood before absconding. This suggests that the remaining 4 treated colonies were going to abscond soon and this is a likely explanation for the beetle effects seen on adult bees, brood, and flight activity in these colonies. None of this behavior was observed in the control European colonies. Therefore, our data clearly indicate that European colonies do respond to large adult small hive beetle infestations by having high, prepared absconding rates.

\subsection{Propolis}

We found that European honey bees used almost 4 times less propolis than Cape honey bees (Tab. I) which is consistent with the findings of others (Bro. Adam, 1983; Ruttner, 1988; Dietz, 1992; Hepburn and Radloff, 1998) though this difference could be due to environmental effects. Because social encapsulation of adult small hive beetles in propolis prisons appears to be a resistance mechanism of African honey bees (Hepburn and Radloff, 1998; Neumann et al., 2001a), this could be a reason European colonies are highly susceptible towards small hive beetle infestations 
while Cape honey bees are more resistant (Tribe, 2000). Cape bees readily use more propolis than do European bees; therefore, more propolis is available in Cape colonies for use in beetle social encapsulation systems. Although imprisoning behavior is also present in European honey bees (Ellis, 2002a) our data suggest that it may not be as efficient as African honey bee imprisoning behavior, possibly due to the lesser use of propolis by European bees.

\subsection{Honey area}

Treatment clearly reduced the amount of honey stores in bee colonies (Tab. I). Because flight activity was not reduced, this difference could be due to the feeding habits of adult beetles (Lundie, 1940; Schmolke, 1974; Ellis et al., $2002 b$ ), or general colony stress conditions due to beetle presence. European treated colonies had no honey stores at the end of the study, possibly reflecting preparation for absconding (Winston et al., 1979; Koeniger and Vorwohl, 1979; Koeniger and Koeniger, 1980; Punchihewa, 1990).

\subsection{Brood}

It has been reported that small hive beetles feed on honey bee eggs and brood (Lundie, 1940; Schmolke, 1974; Elzen et al., 1999; Ellis et al., 2002b) and indeed, that they do so preferentially (Elzen et al., 2000). These data support our finding of significant differences in sealed brood areas between treated and control European honey bee colonies. Despite beetles feeding on bee brood, the major factor contributing to a decline in brood area between treatment and control European honey bee colonies was most likely due to the observed absconding preparation behavior, namely brood abortion and cannibalism. On the other hand, Cape honey bees did not experience the same decline in brood area when infested with hive beetles (Tab. II), also suggesting a superior ability to cope with beetle infestations.

\subsection{Adult bees and bee weight}

The data show that the presence of adult small hive beetles lowers the number of adult bees present in European honey bee colonies, but not in Cape honey bee colonies, although beetle infestations did not compromise bee weight. However, threshold values have not yet been determined. Contrary to what has been reported by others (Wenning, 2001), this shows that beetle larvae are not the only stage of the small hive beetle's life cycle that damages honey bee colonies. European treated colonies also had significantly less brood than control colonies and this is probably related to the differences in adult bee populations between treatments in European colonies.

\subsection{Pollen}

The only striking impact small hive beetle infestations had on infested Cape honey bee colonies was a reduction in pollen stores. It is possible that beetles in these colonies were feeding on pollen stores. Although beetles preferentially feed on bee brood (Elzen et al., 2000), it is evident that Cape bees are efficient at guarding their brood because there was no significant loss of brood area in beetle infested Cape colonies. In these circumstances the beetles would have had to feed on alternative food sources, such as pollen stores. It is well established that beetles feed on pollen (Lundie, 1940; Schmolke, 1974; Elzen et al., 2000; Hood, 2000; Neumann et al., 2001b) and that they reproduce most successfully on a diet of pollen alone (Ellis et al., 2002b). In European colonies the beetles caused a significant reduction in brood area (probably by feeding and ovipositing on it and because of prepared absconding behavior by the bees) and there were no differences in the pollen stores between the treatments. Our data suggest that beetles are restricted to pollen in Cape bee colonies, but gain access to brood in European ones, which likely triggers explosive reproduction by beetles.

\subsection{Flight activity}

The fact that European bees had greater flight activity than Cape bees is probably due to nectar flow differences in each country for the time of year the experiments were conducted. The pertinent information lies in the interactions found between location $\times$ treatment. Our data show that treatment significantly lowered average flight activity in European bee colonies 
but not in Cape ones. Small hive beetle presence in European colonies was sufficient to lower flight activity. Although the causes for this are unknown, it may be that small hive beetles cause general disruption in European colonies (Hood, 2000; Wenning, 2001) and flight behavior is thus compromised. The difference appears related to prepared absconding behavior of the treated European colonies; a behavior that likely limited the number of available foraging workers. Further, Ellis et al. (2003) showed that European honey bees guarding small hive beetle prisons belong to the same age cohort as foraging bees. Therefore, an increasing population of small hive beetles could cause more foraging-age bees to begin guarding beetle prisons thus explaining the overall decrease in flight activity between European treatment and control colonies seen in this study. Increasing beetle densities affected flight activity only in treated European colonies.

\subsection{Beetle counts}

All colonies in both locations were created from colonies having small populations of hive beetles. We believe all colonies started with $<5$ beetles per colony (visual estimates). Therefore, the number of beetles found in Cape control colonies could be considered background noise, being close to the original population of beetles present in the colony at the beginning of the experiment. A total of 2565 small hive beetles were unaccounted for in Cape colonies by the end of the experiment. These beetles were put into the hive, but not re-collected. At the same time our data show that these beetles were not migrating into control colonies. Even though European control colonies had significantly more beetles than did Cape control colonies, they too were not heavily infested with "stray" beetles (unaccounted beetles totaling 4487 individuals in the US).

Why beetles tended to migrate from European non-absconding treated colonies and not from Cape non-absconding treated colonies is unclear. This could be indicative of a superior ability of Cape bees to imprison and guard beetles more efficiently than European bees (Hepburn and Radloff, 1998; Neumann et al., 2001a; Ellis, 2002). Regardless, over half of the beetles introduced into European colonies were not in the hives at the end of the experiment. These beetles may have been host seeking, even though they were not going to control colonies.

Small hive beetle populations in both European absconding and non-absconding treated colonies were the same. This occurred regardless of the number of beetles introduced into the colonies (which totaled 1400 beetles/colony for treated colonies that did not abscond and an average of 617 beetles/colony for treated colonies that absconded). This implies a "carrying capacity" for small hive beetles in European bee colonies. It could also imply a threshold, that when met, European colony health is compromised and, even in extreme situations, absconding preparation begins.

At the same time, the carrying capacity for beetles in Cape colonies is either much higher, or non-existent. We base this on our data showing that most of the beetles put into Cape colonies stayed in those colonies. Because this large number of beetles in Cape colonies never significantly affected measured colony parameters, with the exception of reduced pollen stores (Tab. II), Cape bees must have either superior imprisoning techniques (Hepburn and Radloff, 1998; Neumann et al., 2001a), or other behavioral mechanisms (Elzen et al., 2001) that make them better able to handle large infestations of small hive beetles.

\section{ACKNOWLEDGEMENTS}

We would like to thank Gilbert and Grace Smith for providing the Warren County, Georgia, USA site and also Mr. and Mrs. J.M. Sikes for donating half of the European bees used in the US replicate. Thanks also goes to David Westervelt for providing all small hive beetles used in USA. A special thanks goes to Amanda Ellis, Anna Flügge, and Alexandra Holland for technical assistance. Financial support was provided by the United States Department of Agriculture.

Résumé - Effets des petits coléoptères des ruches adultes, Aethina tumida (Coleoptera, Nitidulidae) sur les nids et le comportement de butinage des colonies d'abeilles domestiques du Cap et européennes. Le Petit Coléoptère des ruches est endémique à l'Afrique sub-saharienne, mais son importance en tant que parasite des colonies d'abeilles domestiques y est négligeable. De fortes infestations par ce parasite peuvent conduire les colonies africaines à déserter. Par contre les colonies 
d'abeilles européennes sont fortement sensibles et peuvent être décimées par le parasite. Nous avons étudié les effets des petits coléoptères des ruches sur l'activité de vol et les nids de 20 colonies d'abeilles domestiques européennes aux USA et de 20 colonies d'abeilles du Cap (Apis mellifera capensis), en Afrique du Sud. Chaque colonie comportait trois cadres d'ouvrières, un cadre de miel, deux cadres de couvain et une reine pondeuse. Les colonies témoins $(\mathrm{N}=10)$ avaient moins de 5 coléoptères par ruche. Les colonies expérimentales ont reçu chacune 100 coléoptères chaque jour durant $15 \mathrm{j}$. Le nombre d'abeilles rentrant à la ruche a été compté deux fois par j. Les colonies qui ont déserté ont été récupérées et analysées. Aux j 16 et 17 toutes les colonies ont été fermées et congelées.

La désertion n'a pas différé significativement entre les traitements et entre les races mais a eu tendance à être plus forte chez les colonies européennes (Tab. I). Les abeilles du Cap ont utilisé plus de propolis et récolté plus de miel que les européennes (Tab. I). Le poids corporel n'a pas différé significativement entre les races. Le nombre d'abeilles, la quantité de couvain et l'activité moyenne de butinage n'ont pas été affectées par le traitement chez les colonies Cap mais ont été réduites chez les européennes (Tab. II). En revanche la quantité de pollen a été réduite chez les abeilles du Cap, mais pas chez les européennes (Tab. II). Le nombre de coléoptères dans les colonies témoins a été significativement plus élevé chez les européennes. Le pourcentage de coléoptères restants chez les colonies expérimentales n'ayant pas déserté a été plus élevé chez les abeilles du Cap.

Nos données montrent que les colonies européennes réagissent aux fortes infestations par une désertion préparée et plus élevée. Puisque l'emprisonnement des petits coléoptères des ruches dans la propolis semble être un mécanisme de résistance des abeilles africaines, la faible utilisation de la propolis par les abeilles européennes peut rendre celles-ci plus sensibles au ravageur. Nos résultats montrent que les coléoptères adultes exercent un effet nuisible sur les colonies européennes, mais pas sur celles d'abeilles du Cap, et indiquent que les colonies d'abeilles du Cap peuvent mieux supporter une plus forte attaque par A. tumida que les colonies européennes.

Aethina tumida / Apis mellifera / Apis mellifera capensis / activité de vol / propolis

Zusammenfassung - Die Effekte adulter kleiner Beutenkäfer Aethina tumida (Coleoptera: Nitidulidae) auf Nester und Flugaktivität von Kaphonigbienen und europäischen Honigbienen (Apis mellifera). Der kleine Beutenkäfer ist endemisch in Afrika südlich der Sahara, wo er geringe Bedeutung als Parasit lokaler Honigbienen hat. Schwere Infektionen afrikanischer Völker können zum "absconding" führen (= nicht reproduktives
Schwärmen). Im Gegensatz dazu können europäische Bienen sehr anfällige Wirte sein. Die Effekte von Beutenkäferinfektionen auf Flugaktivität und Nester von Honigbienen wurden in europäischen Bienen (USA) und in afrikanischen Kaphonigbienen (Apis mellifera capensis, Südafrika) an je 20 Kleinvölkern untersucht (3 Waben mit Bienen, 1 Honigwabe, 2 Pollenwaben, 2 Brutwaben und eine legende Königin, kein Propolis). Die Kontrollvölker $(\mathrm{N}=10)$ hatten $<5$ Käfer. Die Versuchsvölker erhielten je 100 Käfer an 15 aufeinanderfolgenden Tagen. Die Anzahl zurückkehrender Bienen wurde zweimal täglich bestimmt. Abscondete Völker wurden gesammelt und analysiert. Am 16 und 17 Tag wurden alle verbleibenden Völker verschlossen und eingefroren.

Absconding war nicht signifikant verschieden zwischen den Behandlungen oder Unterarten aber tendenziell höher in den europäischen Völkern (Tab. I). Kapbienen benutzten mehr Propolis und sammelten mehr Honig als europäische Bienen (Tab. I). Das Bienengewicht war nicht signifikant verschieden zwischen den Unterarten (Tab. I). Die Behandlung hatte keinen Effekt auf die Anzahl Bienen, Brutmenge und mittlere Flugaktivität bei Kapbienen aber verringerte diese bei europäischen Bienen (Tab. II). Jedoch wurde die Pollenmenge bei Kapbienen durch die Behandlung verringert aber nicht in europäischen Bienen (Tab. II), was darauf hindeutet, dass die Käfer sich vom Pollen ernähren und/oder das Pollenfouragieren erniedrigt wird. Die Anzahl der Käfer war signifikant höher in den europäischen Kontrollen als bei Kapbienen. Der Prozentsatz an verbleibenden Käfern in den nicht abscondeten Versuchsvölkern war jedoch bei Kapbienen höher als bei den europäischen Bienen. Unsere Daten deuten daraufhin, dass europäische Völker auf starke Infektionen mit gezielten Vorbereitungen zum Verlassen des Nestes reagieren, was für die Verringerung der Brutmenge in europäischen Versuchsvölkern relevant sein kann. Da Propolisgefängnisse einen Resistenzmechanismus afrikanischer Bienen darstellen, scheint die geringe Propolisverwendung europäischer Bienen deren Anfälligkeit zu erhöhen. Unsere Daten zeigen, dass adulte Beutenkäfer zwar schädigende Effekte auf europäische Völker aber nicht auf Kapbienenvölker haben. Unsere Ergebnisse deuten daher darauf hin, dass Kapbienenvölker einen größeren Befall mit Beutenkäfern besser tolerieren können als europäische Völker.

Aethina tumida / Apis mellifera / Apis mellifera capensis / Flugaktivität / Honigbienennester

\section{REFERENCES}

Adam Bro. (1983) In Search of the Best Strains of Bees, Northern Bee Books, Mytholmroyd, Hebden Bridge, UK. 
Dietz A. (1992) Honey bees of the world, in: Graham J.M. (Ed.), The hive and the honey bee, Dadant and Sons, Hamilton, Illinois, pp. 23-71.

Ellis J.D. Jr. (2002) Life behind bars: why honey bees feed small hive beetles, Am. Bee J. 142, 267-269.

Ellis J.D. Jr., Neumann P., Hepburn R., Elzen P.J. (2002) Longevity and reproductive success of Aethina tumida (Coleoptera: Nitidulidae) fed different natural diets, J. Econ. Entomol. 95, 902-907.

Ellis J.D. Jr., Holland A.J., Hepburn R., Neumann P., Elzen P.J. (2003) Cape (Apis mellifera capensis) and European (Apis mellifera) honey bee guard age and duration of small hive beetle (Aethina tumida Murray, Coleoptera: Nitidulidae) prison guarding, J. Apic. Res. (in press).

Elzen P.J., Baxter J.R., Westervelt D., Randall C., Delaplane K.S., Cutts L., Wilson W.T. (1999) Field control and biology studies of a new pest species, Aethina tumida Murray (Coleoptera, Nitidulidae), attacking European honey bees in the Western Hemisphere, Apidologie 30, 361-366.

Elzen P.J., Baxter J.R., Westervelt D., Randall C., Wilson W.T. (2000) A scientific note on observations of the small hive beetle, Aethina tumida Murray (Coleoptera, Nitidulidae), in Florida, USA, Apidologie 31, 593-594.

Elzen P.J., Baxter J.R., Neumann P., Solbrig A., Pirk C.W.W., Hepburn R., Westervelt D., Randall C. (2001) Behavior of African and European subspecies of Apis mellifera toward the small hive beetle, Aethina tumida, J. Apic. Res. 40, 40-41.

Hepburn H.R., Magnuson P. (1988) Nectar storage in relation to wax secretion by honeybees, J. Apic. Res. 27, 90-94.

Hepburn H.R., Radloff S.E. (1998) Honeybees of Africa, Springer Verlag, Berlin.

Hepburn H.R., Reece S., Neumann P., Moritz R.F.A., Radloff S.E. (1999) Absconding in honeybees (Apis mellifera) in relation to queenstate and mode of worker reproduction, Insectes Soc. 46, $323-326$.

Hood W.M. (2000) Overview of the small hive beetle, Aethina tumida, in North America, Bee World 81, 129-137.

Koeniger N., Koeniger G. (1980) Observations and experiments on migration and dance communication of Apis dorsata in Sri Lanka, J. Apic. Res. 19, 21-34.

Koeniger N., Vorwohl G. (1979) Competition for food among four sympatric species of Apini in Sri Lanka (Apis dorsata, Apis cerana, and Trigona irridipennis), J. Apic. Res. 18, 95-109.
Lundie A.E. (1940) The small hive beetle, Aethina tumida, Sci. Bull. 220, Union of South Africa, Dept. Agric. Forestry, $30 \mathrm{p}$.

Mutsaers M. (1994) Absconding of honey bee (Apis mellifera adansonii) colonies in south-western Nigeria, related to the seasonal weight of colonies and combs, Proc. 5th Int. Conf. Apiculture in Tropical Climates, IBRA, pp. 3-9.

Nakamura J. (1993) Regulatory system in a honeybee colony toward resource deterioration, Ph.D. Thesis, Tamagawa University, Japan.

Neumann P., Pirk C.W.W., Hepburn H.R., Solbrig A.J., Ratnieks F.L.W., Elzen P.J., Baxter J.R. (2001a) Social encapsulation of beetle parasites by Cape honeybee colonies (Apis mellifera capensis Esch.), Naturwissenschaften 88, 214-216.

Neumann P., Pirk C.W.W., Hepburn H.R., Elzen P.J., Baxter J.R. (2001b) Laboratory rearing of small hive beetles Aethina tumida (Coleoptera, Nitidulidae), J. Apic. Res. 40, 111-112.

Punchihewa R.W.K., Koeniger N., Howpage D. (1990) Absconding behaviour of Apis cerana in Sri Lanka, in: Proc. 11th Int. Cong. IUSSI, India, pp. 106-107.

Ruttner F. (1988) Biogeography and Taxonomy of Honeybees, Springer Verlag, Berlin, Germany.

Simpson J. (1959) Variation in the incidence of swarming among colonies of Apis mellifera throughout summer, Insectes Soc. 6, 85-89.

Schmolke M.D. (1974) A study of Aethina tumida: the small hive beetle, University of Rhodesia Certificate in Field Ecology Project Report, $178 \mathrm{p}$.

Tribe G.D. (2000) A migrating swarm of small hive beetles (Aethina tumida Murray), S. Afr. Bee J. 72, 121-122.

Wenning C.J. (2001) Spread and threat of the small hive beetle, Am. Bee J. 141, 640-643.

Winston M.L. (1992) The honey bee colony: life history, in: Graham J.M. (Ed.), The hive and the honey bee, Dadant and Sons, Hamilton, Illinois, pp. 73-101.

Winston M.L., Otis G.W., Taylor O.R. Jr. (1979) Absconding behavior of the Africanized honeybee in South America, J. Apic. Res. 18, 85-94.

Woyke J. (1976) Brood-rearing efficiency and absconding in Indian honeybees, J. Apic. Res. 15, 133-143.

Woyke J. (1989) Biology and management of African bees Apis mellifera adansonii in Africa, 32nd Int. Apic. Congr., Apimondia, Bucharest, Romania, pp. 44-47. 